\title{
What drives voluntary adoption of farming practices that can abate nutrient pollution?
}

\author{
Z.R. Luther, S.M. Swinton, and B. Van Deynze
}

\begin{abstract}
Agricultural nutrient runoff and leaching into groundwater can impose societal costs that may be external to farmer decisions. Farmers can reduce the environmental impact of nutrient losses by adopting conservation and precision nutrient diagnostic and application practices. We examine the determinants of adoption decisions of such practices using mail survey data from a large, stratified sample of corn (Zea mays L.) and soybean (Glycine max [L.] Merr.) farmers in the US eastern Corn Belt.Via an ordered probit that captures both adoption and intent to adopt eight different practices, we evaluate a broad range of potential factors driving adoption of conservation and precision agriculture practices. We find that farmer objectives other than income, such as preferences for environmental amenities or social status, were important adoption drivers for conservation and precision technologies, respectively. Livestock farms had a distinct adoption profile, with greater likelihood to adopt cover cropping and less to adopt precision technologies. Farmers who participated in working lands programs were more likely to adopt both cover cropping and precision soil testing technologies. Policies and messaging to encourage voluntary adoption of practices to reduce agricultural nutrient loss should account for farmer objectives, farming systems, and existing policy incentives.
\end{abstract}

Key words: agriculture-conservation practices-nutrient pollution-precision agriculture-technology adoption

Farmers can abate nutrient pollution by adopting a variety of practices and technologies; identifying which farmers are drawn to specific pollution-abating practices and technologies can improve the efficiency of conservation policy and education. Agricultural nutrient loss entails costs both public and private. Nutrient runoff leads to hypoxia and eutrophication in bodies of water both near and far from the initial agricultural site (Selman and Greenhalgh 2009). In addition to surface movement, nitrate nitrogen $\left(\mathrm{NO}_{3}-\mathrm{N}\right)$ and phosphorus $(\mathrm{P})$ move in dissolved form into ground water (King et al. 2015). Soil erosion imposes private costs by degrading the quality and quantity of topsoil, as well as external social costs, such as for dredging of navigable waterways (Pimentel et al. 1995).

Crop farmers can reduce their contributions to soil nutrient loss by adopting a variety of distinct management practices that abate nutrient pollution relative to their existing activities. Conservation practices, such as cover cropping, conservation tillage, and edge-of-field buffer strips, aim primarily for environmental benefits. Precision agriculture practices, which either aid in diagnosing nutrient needs ("diagnostic practices") or in applying nutrients at optimal rates ("application practices"), chiefly target augmenting crop yields and providing cost savings to farmers. However, they also have the potential to reduce nutrient pollution by improving the efficiency of when, where, and how much nutrients are applied (Finger et al. 2019). In order to inform the design of programs encouraging wider adoption of these practices, it is important for policymakers to understand the traits of farmers who gravitate toward different practices, and why they do so. Such understanding can allow policymakers to target scarce resources toward farmers who are most likely to be responsive to tailored messages or conservation programs.

A large body of literature analyzes why farmers adopt technologies, including conservation practices (Feder et al. 1985; Feder and Umali 1993; Abadi Ghadim and Pannell 1999; Daberkow and McBride 2003; Pannell et al. 2006; Knowler and Bradshaw 2007; Prokopy et al. 2008, 2019; Baumgart-Getz et al. 2012; Pierpaoli et al. 2013). The literature generally highlights the importance of five broad categories of adoption drivers: (1) farmer traits, (2) farm resources, (3) technology traits, (4) information sources, and (5) social networks.

In elaborating upon these categories, we posit that three classes of drivers are particularly relevant in the development of targeted policy and education: (1) farmer objectives, (2) technology compatibility with existing systems, and (3) policy incentives. Among farmer objectives, much is known about income-related motives (including risk-adjusted expected utility) (Feder et al. 1985; Feder and Umali 1993), but the literature about nonmonetary drivers, such as environmental ethic or social status, is still emerging (Pannell et al.2006; Prokopy et al. 2008, 2019; Chouinard et al. 2008; Baumgart-Getz et al. 2012). Likewise, the effects of farming system compatibility with specific practices, particularly livestock versus crop-oriented farming systems, is less studied (with the notable exception of Traxler and Byerlee 1993). Greater understanding of these classes of drivers can facilitate messaging about a practice's benefits tailored to a farmer's specific operation and motivations. Finally, while there are many studies of policy effects (Lichtenberg and Smith-Ramirez 2011; Mezzatesta et al. 2013; Claassen et al. 2014; Fleming 2017), few general studies of farm technology adoption drivers test for the effects of policy variables. We aim to test for the importance of these three types of adoption drivers, while

Zachary R. Luther is a doctoral student in the Department of Economics at Vanderbilt University, Nashville, Tennessee. Scott M. Swinton is a university distinguished professor in the Department of Agricultural, Food, and Resource Economics at Michigan State University, East Lansing, Michigan. Braeden Van Deynze is a postdoctoral research associate at the School of Marine and Environmental Affairs, University of Washington, Seattle, Washington. 
controlling for other important drivers identified in previous studies, in the adoption of both conservation practices and precision agriculture technologies. By bringing to bear a large cross-sectional data set from the US eastern Corn Belt that explores four levels of adoption commitment, we draw on a strong data set.

The rest of this paper unfolds by drawing lessons from the existing farm technology adoption literature. That literature review informs the key categories of adoption drivers as well as expectations about drivers particularly relevant to the adoption of eight specific practices that can abate agricultural nutrient pollution. We then introduce the data, gathered via a producer survey covering four midwestern states; develop empirically testable hypotheses; and present our econometric methods. Finally, we present the results of our empirical model with hypothesis tests, discuss these results, and provide insights to inform the design of policies that more efficiently encourage farmer adoption of nutrient loss abatement practices.

Lessons from the Literature. The literature on technology adoption in agriculture is vast and has spawned several excellent reviews (Feder et al. 1985; Feder and Umali 1993), including subcategory on the adoption of conservation practices (Pannell et al. 2006; Knowler and Bradshaw 2007; Prokopy et al. 2008, 2019; Baumgart-Getz et al. 2012). Virtually all approaches to understanding agricultural technology adoption view it as a decision process that is shaped by the farmer's objectives, resources, and the traits of the specific technology or practice in play.

As the literature on farmer objectives has evolved, it has recognized a greater diversity of farmer objectives. The literature from the 1970s and 1980s that focused on adoption of high-yielding crop varieties tended to assume that farmers sought to build wealth, although they might be aiming to optimize a risk-weighted, expected utility function defined over monetary returns (Feder et al. 1985; Feder and Umali 1993). This implied that relevant drivers of adoption included attitudes toward income risk, as well as factors affecting profitability and riskiness inherent in a technology. More recent literature, especially that by sociologists and economists studying conservation technologies, has identified a broader set of objectives that shape farmer adoption choices. Among these multiple objectives are environmental stewardship (Maybery et al. 2005; Pannell et al. 2006; Prokopy et al. 2008, 2019; Chouinard et al. 2008; Greiner and Gregg 2011; Baumgart-Getz et al. 2012; Ranjan et al. 2019), social approval, personal ethics, and work-life balance (Maybery et al. 2005; Pannsell et al. 2006; Greiner and Gregg 2011; Roesch-McNally et al. 2018). One common term to describe the nonmonetary objectives is "attitudes," which have been widely shown to influence farm technology choices, especially related to conservation practices (Prokopy et al. 2008, 2019; Baumgart-Getz et al. 2012).

Farmer and farm household traits also tend to shape the adoption of conservation practices. One is age: older farmers tend to be less inclined to adopt conservation practices (Feder and Umali 1993; Prokopy et al. 2008, 2019; Baumgart-Getz et al. 2012). A second is education: higher levels tend to favor adoption (Feder and Umali 1993; Prokopy et al. 2008, 2019), especially of more complex technologies (Pannell et al 2006). For labor-demanding technologies, larger households with more working-age members facilitate adoption of new practices (Feder et al. 1985; Prokopy et al. 2008). Particularly for the adoption of technologies that are costly, such as those embodied in capital equipment, existing wealth, off-farm income, and access to credit tend to favor adoption of new technologies (Feder et al 1985; Knowler and Bradshaw 2007). The literature also highlights the influence of social networks (Micheels and Nolan 2016; Hunecke et al. 2017), both to assist with learning (Besley and Case 1993; Conley and Udry 2010) and to build household support related to costly adoption decisions that are difficult to test ahead of time and costly to undo (Pannell et al. 2006).

Farm biophysical resources also tend have a strong effect on adoption of agricultural technologies, including conservation ones. Larger farms tend to adopt new technologies more readily for a variety of reasons, including greater access to capital and greater scale (which augments benefits for a profitable technology and spreads fixed costs like equipment and information acquisition) (Feder et al. 1985; Knowler and Bradshaw 2007; Pannell et al. 2006; Prokopy et al. 2008, 2019; Finger et al. 2019). Better resource quality— such as soil fertility or access to clean water-also favors adoption of new technologies, particularly productive ones (Feder et al. 1985) and technologies that rely on a particular resource (e.g., irrigation-dependent crops on irrigation) (Feder and Umali 1993). Land tenure security and the expectation of passing on the farm to the next generation tend to favor the adoption of conservation technologies that gradually build up a farm resource (like soil quality) (Feder and Umali 1993; Gebremedhin and Swinton 2003; Pannell et al. 2006; Baumgart-Getz et al. 2012). Finally, the nature of the farm's agricultural system tends to affect its compatibility with certain alternative practices. For example, farms that have livestock may value forage crops or forage byproducts more than crop farms, which can make them less prone to adopt technologies that substitute forage biomass for grain biomass (Traxler and Byerlee 1993). Likewise, crop-oriented conservation technologies may be less appealing to livestock farmers whose focus is on their animals (Prokopy et al. 2008). Looking at farm resources in a regional sense, the existence of input suppliers and product markets may also favor adoption of new enterprises or practices that rely on specialized inputs (Feder et al. 1985; Feder and Umali 1993).

Information represents a special kind of resource that can influence the adoption of agricultural conservation practices in two ways. First, awareness is a necessary condition for adoption; farmers who are unaware of a practice will not adopt it. So on the information supply side, access to information tends to drive technology adoption, whether the information be from public sources (like extension) or private ones (like marketing messages) (Prokopy et al. 2008). On the information demand side, farmer awareness and interest (e.g., of risks to environmental quality, of potential benefits from a new practice) tend to drive adoption of relevant technologies (Prokopy et al. 2008, 2019; Baumgart-Getz et al. 2012). Given that information acquisition happens gradually, time to learn about how to use a technology also augments adoption levels (Feder et al. 1985; Pannell et al. 2006).

The specific traits of a potential practice or agricultural technology interface with farmer objectives and resource characteristics to influence adoption decisions. Whether the technology is divisible (so that it can be adopted incrementally) or indivisible (so that it must be adopted all at once) has a strong effect, with divisible technologies adopted much more rapidly (Feder et al. 1985; Feder 
and Umali 1993; Pannell et al. 2006). The adoption process can be especially slow for technologies that are embodied in capital goods, like no-till planting equipment (Krause et al. 1990). Particularly for risk averse farmers, risk-reducing technologies tend to be attractive (Feder et al. 1985). Because new technologies are relatively unfamiliar, by definition, farmers tend to prefer ones that can be tested out (are "trialable"), because learning about the technology can reduce the risks both of buyer's remorse and of inefficient use of the new practice (Abadi Ghadim and Pannell 1999; Pannell et al. 2006; Mascia and Mills 2018). Trialability is especially valued by risk averse decision makers. Finally, any new practice must pass an internal benefit-cost analysis on the farm that compares it to the current alternative (Abadi Ghadim and Pannell 1999; Pannell et al. 2006).

\section{Materials and Methods}

Survey Methods. To study corn (Zea mays L.) and soybean (Glycine max [L.] Merr.) farmers' adoption of conservation and precision agriculture practices, our research focused on four states in the eastern Corn Belt: (1) Illinois, (2) Indiana, (3) Ohio, and (4) Michigan. The data for our study came from a mail survey of farmers who were the main decision makers on their farm. This questionnaire, the 2017 Crop Management and Stewardship Practices survey, was developed at Michigan State University and cosponsored by researchers at Purdue University and The Ohio State University. The survey was mailed in February of 2017, and farmer responses were accepted through April of 2017.

Crop farmers were included in the sampling frame if they had planted at least $100 \mathrm{ac}$ (40 ha) of corn or soybean in 2016 and resided in a county where at least $15 \%$ of total land area was planted in corn or soybean. Figure 1 illustrates the counties sampled in these four states. Addresses for 10,582 farmers across the region were purchased from Farm Market iD, an agricultural data firm. Using county-level operation counts from the USDA National Agricultural Statistics Service 2012 Census of Agriculture as the assumed population, we created one stratum at the state level, and two substrata within each state, covering farms above and below 500 planted ac (202 ha). We intentionally oversampled large-acreage farmers in order to capture how most land is managed in these four states and in antic-

\section{Figure 1}

States and counties sampled.

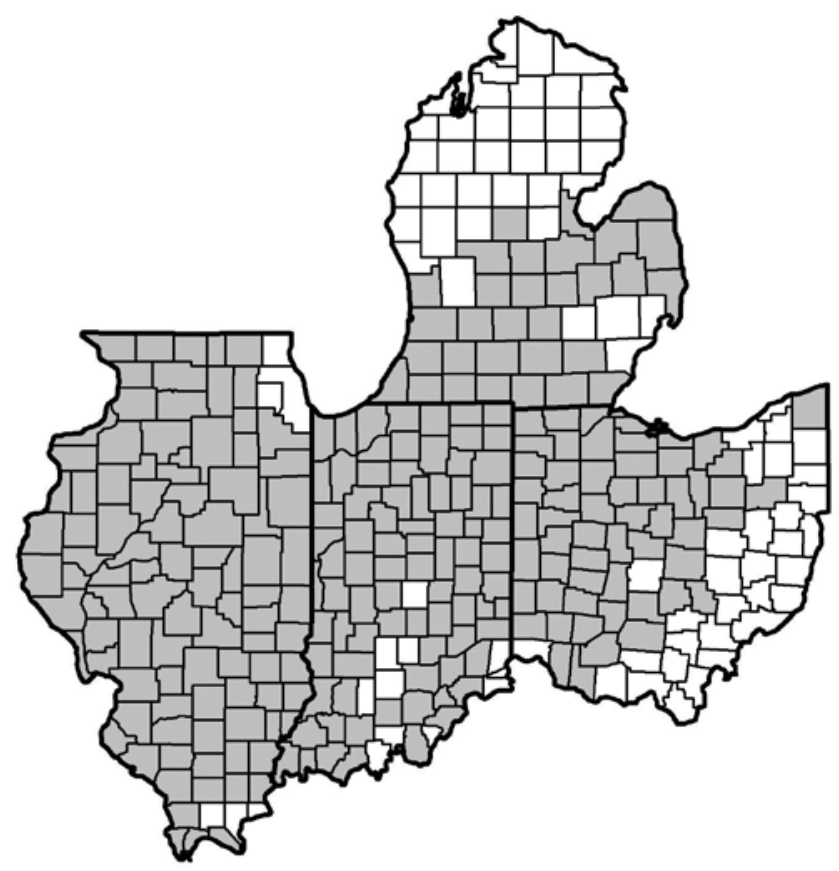

ipation of lower response rates among this group. Of the 10,582 addresses contacted, 3,263 responded, for a $30.8 \%$ response rate. Of these, 1,129 were complete records, suitable for our analysis.

Characterizing Examined Practices. This research explores what factors drive the adoption of eight conservation and precision agriculture technologies, selected to represent two broad types of tools that farmers can use to reduce nutrient loss. First, conservation technologies keep nutrients in place. Second, precision agriculture technologies use information and variable rate application to reduce the application of nutrients where they are not needed (and augment them where they are). We further distinguish within precision agriculture technologies by distinguishing between applicative and diagnostic technologies (Finger et al. 2019). Applicative technologies adjust management actions dynamically based on field or subfield level information. Diagnostic technologies collect field or subfield level information that farmers can use to inform future management decisions.

This study examines a single conservation technology, cover crops, which protects the soil when a main season crop is not holding it in place. Cover crops offer clear environmental benefits by reducing soil erosion and retaining soluble nutrients in the organic matter of the cover crop. While cover crops often lack product markets, they can be grazed or killed in place to build soil organic matter.

We examine the adoption of seven precision agriculture technologies, including three applicative technologies and four diagnostic ones. The three variable rate (VR) application technologies manage fertilizer and seed inputs. Variable rate phosphorus and potassium (VR-P/K) and variable rate nitrogen (VR-N) allow spatial adjustment of nutrient application to meet crop needs. Variable rate seeding (VR-Seeding) allows crop seed planting according to the expected crop yield potential. Variable rate application of nutrients helps to prevent excess application of nutrients where they are not needed, thereby reducing nutrient pollution of surface and ground water. Variable rate seeding can affect nutrient pollution more indirectly by enabling denser planting (especially of corn) where field conditions support higher yields and sparser planting where yield potential is lower.

The four diagnostic technologies examined are more varied in how they function. Pre-sidedress $\mathrm{NO}_{3}^{-}$testing (PSNT) entails the just-in-time evaluation of $\mathrm{N}$ needs for corn. Unlike the spatial precision agriculture technologies, this diagnostic technology is 
temporally specific. By providing the farmer with updated soil $\mathrm{NO}_{3}^{-}$information, it can deter the overapplication of $\mathrm{N}$ fertilizer. Soil nutrient mapping builds maps from soil trait and test information. Those maps can then guide VR fertilizer applications.

Aerial scouting is a diagnostic practice involving the use of imagery gathered from above. Such imagery can capture the vegetative vigor across a farm field during the growing season, thereby informing water, nutrient, pest, and disease management decisions with spatial and temporal precision. In recent years, aerial scouting has begun spreading rapidly, as unmanned aerial vehicles (drones) (1) lower the cost of imagery acquisition, relative to piloted airplanes, and (2) improve spatial precision relative to satellite images.

The last diagnostic technology, yield mapping, uses yield monitors to make a spatial record of crop yields. Yield maps can help inform farmers' planting and field management decisions in the next growing season, potentially reducing nutrient loss via spatial management of fertilizers and seeding rates.

Relevant Drivers and Hypothesized Effects. Drawing upon the categories of explanatory variables identified above, we present a set of testable hypotheses about how the following four categories of major drivers impact farmer decisions on the adoption of practices that abate nutrient losses from crop fields: (1) farmer objectives, (2) farm household traits, (3) farm resources, and (4) information access. For clarity, we state the hypotheses in affirmative form rather than the rejectable, null form preferred by statisticians. We separate our hypotheses by category of the technology, including (1) conservation practices that keep nutrients in place (e.g., cover crops), and (2) precision agriculture practices that target nutrients for resource-efficient, optimal crop growth. As noted above, we subdivide the precision agriculture practices into two groups: (1) applicative precision technologies (VR-P/K, VR-N, and VR-Seeding), and (2) diagnostic precision technologies (e.g., PSNT, soil nutrient mapping, aerial scouting, and yield mapping) (Finger et al. 2019).

Farmer objectives, as identified through stated attitudes, are expected to be strong drivers of adoption choices (table 1). We hypothesize that income-oriented farmers and those motivated by social status will adopt precision agriculture technologies. We

Table 1

Hypotheses to be tested for four types of adoption driver.

\begin{tabular}{|c|c|c|}
\hline \multirow[b]{2}{*}{ Hypothesis by type of adoption driver } & \multicolumn{2}{|c|}{ Type of practice and ex } \\
\hline & Conservation & Pre \\
\hline \multicolumn{3}{|l|}{ Farmer objective } \\
\hline Income-oriented attitude (relative advantage criterion) & n.a. & $(+)$ \\
\hline Environmentally oriented attitude & $(+)$ & n.a. \\
\hline Social status oriented attitude & n.a. & $(+)$ \\
\hline \multicolumn{3}{|l|}{ Farmer and household traits } \\
\hline Age $(y)$ & $(-)$ & $(-)$ \\
\hline Education (level) & $(+)$ & $(+)$ \\
\hline Family members (number) (Labor resource indicator) & $(+)$ & n.a. \\
\hline $\begin{array}{l}\text { Crop insurance (proportion of crop acres) (*Risk } \\
\text { reducing tech) }\end{array}$ & n.a. & $(+)$ \\
\hline \multicolumn{2}{|l|}{ Working lands conservation program participator (binary) (+) } & n.a. \\
\hline Set-aside conservation program participator (binary) & n.a. & n.a. \\
\hline \multicolumn{3}{|l|}{ Farm resources } \\
\hline $\begin{array}{l}\text { Cropped area (ac) (Farm size indicator; *Indivisible } \\
\text { precision tech.) }\end{array}$ & n.a. & $(+)$ \\
\hline Own land share (proportion) (Tenure/capital indicator) & $(+)$ & n.a. \\
\hline \multicolumn{2}{|l|}{ Bequeath farm expected (binary) (Time horizon indicator) (+) } & n.a. \\
\hline Livestock farm (binary) (Agricultural system type) & $(+)$ & $(-)$ \\
\hline \multicolumn{3}{|l|}{ Information access } \\
\hline Public source: Extension or faculty (binary) & n.a. & n.a. \\
\hline Private vendor: Seed or chemical dealer & n.a. & n.a. \\
\hline Private consultant & n.a. & n.a. \\
\hline Other: Web, print, grower association & n.a. & \\
\hline
\end{tabular}

Note: + denotes positive, - denotes negative, and n.a. denotes no a priori hypothesis on the direction of expected effect.

*Indicates where technology traits, the fifth adoption driver, interacts with included variables to influence hypothesized effect.

expect environmentally oriented farmers to adopt conservation technologies.

Among farmer and farm household traits (table 1), literature leads us to hypothesize that older farmers will be less inclined to adopt either type of technology. By contrast, we expect that more educated farmers will adopt both conservation and precision agriculture practices. Because cover cropping entails additional tasks and hence demands more labor than the precision technologies, we expect that larger families with more available labor will be more likely to adopt conservation technologies. As crop insurance enrollment mitigates risk of financial loss for farmers, we expect that farmers who have insured a larger share of their cropped acreage will be more inclined to adopt precision technologies because information can increase a farmer's awareness of his or her operation's vulnerability to financial loss (and these are information-intensive technologies). Finally, because conservation subsidy programs reduce the cost of adopting conservation practices, we expect that participation in a working lands program will favor adoption of conservation practices, but that participation in a set-aside conservation program will have no effect.

Farm resources (table 1) start with an indicator of farm size, which serves as our proxy for farm wealth. We measure farm size as the sum of owned and rented acres, since larger farms tend to own big equipment and rent more land (the Pearson correlation coefficient between owned and rented land in our survey was +0.15). We hypothesize that farms with more cropped acreage will be more inclined to adopt an indivisible technology like those embodied in precision agriculture equipment (notably yield monitors and variable rate applicators). We expect that farmers with a long time horizon, as indicated by owning a large share of the cropland they operate or by the intent to bequeath the farm to heirs, will be more 
likely to adopt conservation practices that enhance soil quality. Finally, regarding compatibility of agricultural systems with new technologies, we expect that cover cropping will be attractive to livestock farmers as a source of forage. By contrast, we expect that livestock farmers will be disinclined to invest money and time in precision cropping practices (though they would likely take an interest in precision livestock practices, had we measured any of these). We define livestock farmers as farmers for whom (1) milk and dairy products, and/or (2) livestock and animal products other than dairy, account for more than $10 \%$ of farm revenues.

Our literature review indicates that an additional category of drivers, information, can play an important role in practice and technology adoption decisions. Information availability can have hard-to-predict effects for at least two reasons. First, the effect of information on adoption decisions depends on prior information available to the decision maker-a prior state that we do not observe with our cross-sectional survey data. Second, decision makers choose their information sources, so the information effect is endogenous to the decision to seek it out. In the data set explored here, we lack information on stated awareness or familiarity with examined practices beyond the level of adoption. Because the potential role of information as a driver of adoption is complex and dynamic, we include a series of variables measuring the frequency with which farmers consult each of nine distinct information sources as controls for information access without hypothesizing about their expected effects on the adoption of specific practices (table 1). The nine information sources are (1) university extension, (2) university faculty, (3) chemical input dealers, (4) seed input dealers, (5) independent crop consultants, (6) other farmers, (7) grower associations, (8) the Web, and (9) print sources. Frequency of access is measured on a five-point scale ranging from never (1) to once a day (5).

Key Explanatory Variables. Table 2 presents summary statistics for the key independent variables. The survey sample was stratified by state and farm size, which entailed oversampling important groups with historically low response rates, such as large farms. In order to adjust the statistical results to account for different probabilities of subpopulations being sampled, we use probability weights in order to permit extrapolation from the

Table 2

Summary statistics for 13 independent variables.

\begin{tabular}{|c|c|c|c|c|c|}
\hline Variable & Unit & Mean & SD & Min. & Max. \\
\hline Cropland & Acres & 612 & 16.2 & 6 & 14,500 \\
\hline Own land share & Proportion & 0.501 & 0.015 & 0 & 1 \\
\hline Labor force & Number of persons & 0.689 & 0.0563 & 0 & 136 \\
\hline Livestock farm & $0 / 1$ & 0.207 & n.a. & 0 & 1 \\
\hline Age & Years & 61.9 & 0.442 & 28 & 99 \\
\hline Educational level & Integer & 2.85 & 0.033 & 1 & 4 \\
\hline $\begin{array}{l}\text { Working lands conservation } \\
\text { program participator }\end{array}$ & $0 / 1$ & 0.110 & n.a. & 0 & 1 \\
\hline Crop insurance enrollment & $\begin{array}{l}\text { Proportion of } \\
\text { crop acres }\end{array}$ & 0.750 & 0.016 & 0 & 1 \\
\hline $\begin{array}{l}\text { Set-aside conservation } \\
\text { program participator }\end{array}$ & $0 / 1$ & 0.281 & n.a. & 0 & 1 \\
\hline Bequeath intent & $0 / 1$ & 0.658 & n.a. & 0 & 1 \\
\hline State: Illinois & $0 / 1$ & 0.493 & n.a. & 0 & 1 \\
\hline State: Indiana & $0 / 1$ & 0.236 & n.a. & 0 & 1 \\
\hline State: Michigan & $0 / 1$ & 0.097 & n.a. & 0 & 1 \\
\hline State: Ohio & $0 / 1$ & 0.174 & n.a. & 0 & 1 \\
\hline
\end{tabular}

Table 3

Probability weights by stratum.

\begin{tabular}{lccc}
\hline Strata & Strata population size & $\begin{array}{l}\text { Strata response } \\
\text { sample size }\end{array}$ & Probability weight \\
\hline Illinois, large farms & 7,492 & 253 & 29.61 \\
Illinois, smaller farms & 14,980 & 129 & 116.12 \\
Indiana, large farms & 3,578 & 159 & 22.50 \\
Indiana, smaller farms & 7,153 & 109 & 65.62 \\
Michigan, large farms & 1,039 & 108 & 9.62 \\
Michigan, smaller farms & 3,370 & 41 & 82.20 \\
Ohio, large farms & 1,584 & 186 & 8.52 \\
Ohio, smaller farms & 6,355 & 144 & 44.13 \\
& & &
\end{tabular}

stratified sample to the broader population of corn and soybean farms with over 100 ac (40 ha) in the states of Illinois, Indiana, Michigan, and Ohio. Table 3 details how the inverse sampling probability weights were calculated based on the stratum-level response sample and the associated stratum population. All statistical results presented here are computed using these probability weights. For interested readers, we make unweighted results from the ordered probit analysis available in the supplemental material for this article, which can be found online at http://dx.doi.org/10.22004/ ag.econ.302418 (Solon et al. 2015).

Factor Analysis of Farmer Attitudes. We measured farmer objectives indirectly via latent attitude factors that were constructed from levels of agreement with Likert-scaled statements. We used a confirmatory factor analysis to characterize the latent attitudes that might influence a farmer's decision to adopt a certain practice. There were 11 statements regarding respondent attitudes toward social status, income, and environmental stewardship. As these variables were measured on a 5-point Likert scale, many were correlated with one another. Through factor analysis, we reduced the 11 Likert variables to the following three attitudinal factors: (1) preference for income, (2) preference for high social status, and (3) preference for environmental amenities, respectively.

Table 4 presents the factors and analogous factor loadings to these 11 statements. These loadings are used to generate attitudinal scores for each farmer that, by construction, 
have mean zero with unit variance. The 3 attitudinal factors are described as follows:

- The "Income" factor experiences high loadings on statements about optimizing income;

- The "Social status" factor sees high loadings on statements regarding preference for a higher social status in their community;

- The "Environmental" factor has high loadings on preferences for environmental amenities and stewardship.

In the following analyses of technology adoption, these factors are included to represent the farmer objectives inherent in their latent attitudes.

Ordered Probit Analysis. In order to test hypotheses statistically, we employed an ordered probit analysis to assess the factors driving adoption of the eight conservation and precision agriculture practices. The state of adoption of each practice, the dependent variable in each ordered probit model, was self-reported by the farmer at one of four levels: (1) never used, don't want to; (2) never used, might; (3) use sometimes; or (4) use regularly. We control for state-level fixed effects by including dummy variables for Illinois, Indiana, and Ohio, using Michigan farmers as the base group. We also weight by stratum by using the probability weights described in table 3 . The ordered probit models were estimated via maximum likelihood. The estimated coefficients are not easily converted to marginal effects, so we draw inferences from their sign and significance, rather than from their magnitudes.

\section{Results and Discussion}

We begin this section by describing adoption rates of the eight practices presented above. Afterwards, we discuss our results, separated by the hypotheses delineated in table 1 .

Adoption Levels of Studied Practices. The relative adoption rates of the eight technologies, described in the Characterizing Examined Practices section, among farmers in the eastern Corn Belt in 2017 are captured in figures $2 \mathrm{a}$ and $2 \mathrm{~b}$. The precision agriculture technologies, including both mapping and variable rate application, are the mostly widely adopted. Soil nutrient mapping (figure $2 \mathrm{~b}$ ) is the most popular, with approximately $60 \%$ of respondents using it regularly and just under $20 \%$ more using it at least sometimes. VR-P/K (figure $2 \mathrm{a}$ ) is the second most widely used practice, being used at least sometimes by approximately $60 \%$ of

Table 4

Factor loadings from confirmatory factor analysis for three latent variables.

\begin{tabular}{lll}
\hline Variable & Value statement & Factor loading \\
\hline Income & Earn a high income & 1.00 \\
& Build up wealth and family assets & 1.02 \\
& Minimize debt & 0.54 \\
& Maximize farm/company profit & 0.77 \\
\hline Social status & Be among the best in the industry & 1.00 \\
& Keep family tradition of farming alive & 0.75 \\
& Pass on the land in good condition & 0.59 \\
& Have good looking fields & 0.84 \\
\hline Environmental & Maintain good hunting, fishing, and hiking nearby & 1.00 \\
& Look after the environment & 1.23 \\
& (Mean concern about agriculture's contribution to & 0.51 \\
& environmental damage) &
\end{tabular}

\section{Figure 2}

(a) Level of adoption of conservation practice and applicative precision technologies. (b) Level of adoption of diagnostic precision technologies. VR = variable rate; $\mathrm{PSNT}=$ pre-sidedress nitrate testing.

(a)

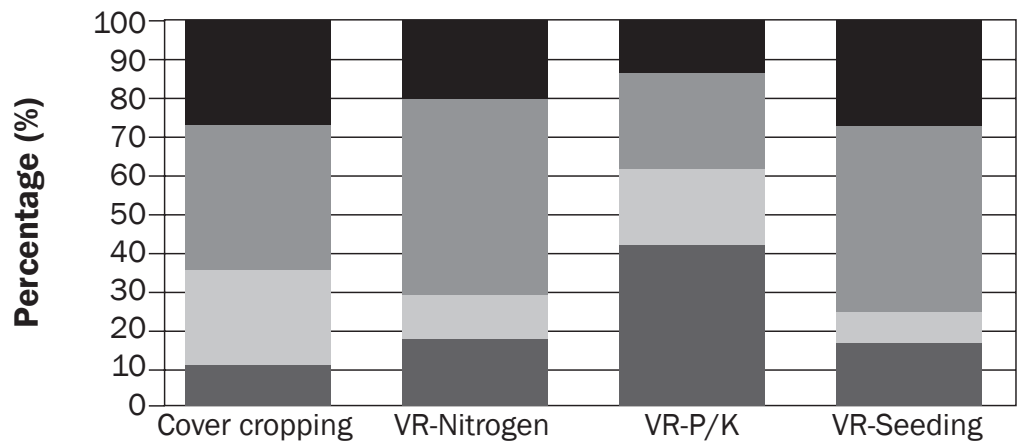

(b)

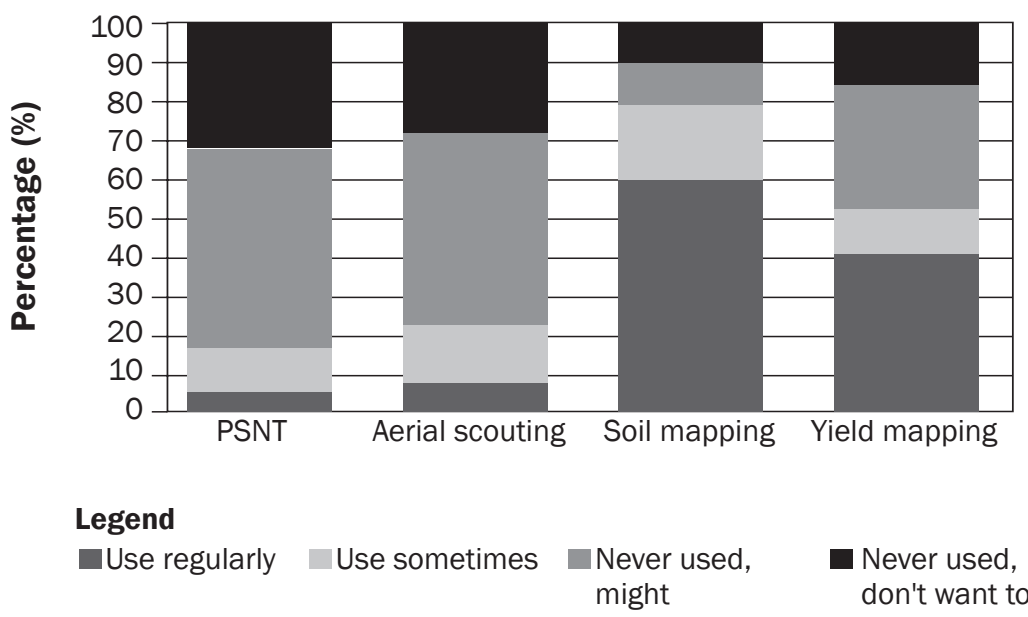

respondents.Yield mapping (figure $2 \mathrm{~b}$ ) is also a popular practice, with over $40 \%$ using it regularly and another $10 \%$ using it at least sometimes. The other five practices were used sometimes by no more than $35 \%$ of respondents. From most to least used "sometimes," they are cover cropping ( 35\%), VR-N ( 29\%), VR-Seeding ( 25\%), aerial scouting $(\sim 22 \%)$, and PSNT $(\sim 18 \%)$. 
Farmer Objective Drivers. As hypothesized, adoption of cover cropping is more likely among farmers with a high preference for environmental amenities and stewardship (table 5). While we also hypothesized that social status would drive the likelihood of adopting precision agriculture practices, in the analysis with survey weights, we found that to be the case only for the adoption of soil nutrient mapping (table 6). However, in the unweighted analysis, the adoption of aerial scouting is also more likely among farmers with a social status objective (table A6 in the supplemental material, which can be found online at http://dx.doi. org/10.22004/ag.econ.302418). Contrary to our hypothesis that income-oriented farmers adopt precision technology practices, we found that adoption of soil mapping was actually less likely among income-oriented farmers (table 6).

Farmer and Household Trait Drivers. As postulated, the adoption of cover cropping was more likely among livestock farmers (table 7). In further support of our hypotheses about livestock farmers, being a livestock farmer decreased the likelihood of adoption of three precision agriculture technologies: (1) VR-P/K, (2) soil nutrient mapping, and (3) yield mapping (tables 7 and 8).

Older farmers are less likely to adopt five of the eight practices that are the focus of this study: (1) cover cropping, (2) VR-Seeding, (3) aerial scouting, (4) soil nutrient mapping, and (5) yield mapping - supporting our hypotheses and echoing much of the current literature.

More educated farmers are more likely to adopt aerial scouting, soil nutrient mapping, and yield mapping, supporting our hypothesis that greater education would favor the adoption of precision agriculture practices (table 8). However, education had no effect on the adoption of cover cropping, contrary to our expectation.

We find no evidence that having a higher supply of labor increases the likelihood of adopting cover cropping (table 7), contrary to our hypothesis. While we had no expectations of labor effects on precision agriculture practice adoption, we find that farms with less labor are more likely to adopt VR-P/K (table 7). However, this relationship does not hold for the other precision technologies.

As expected, participation in working lands environmental stewardship programs increases the likelihood of adopting cover cropping (table 7). Although we had no expectation

\section{Table 5}

Attitudinal determinants of adoption of conservation practice and applicative precision technologies (survey-weighted ordered probit regression).

\begin{tabular}{lcccc}
\hline Variables & Cover cropping & VR-N & VR-P/K & VR-seeding \\
\hline Income & -0.149 & -0.0260 & $5.84 \times 10^{-6}$ & -0.118 \\
& $(0.165)$ & $(0.197)$ & $(0.175)$ & $(0.166)$ \\
Environmental & $0.432 * *$ & -0.0899 & 0.144 & -0.100 \\
& $(0.193)$ & $(0.219)$ & $(0.194)$ & $(0.181)$ \\
Social status & -0.143 & 0.0898 & -0.0443 & 0.286 \\
& $(0.283)$ & $(0.340)$ & $(0.299)$ & $(0.275)$ \\
Pseudo R-squared & 0.107 & 0.0264 & 0.0515 & 0.110 \\
\hline
\end{tabular}

Notes: Significance ( $t$-test probability $>0$ ): $* * * 1 \% ; * \star 5 \% ; * 10 \%$. Robust standard errors in parentheses. VR-N = variable rate nitrogen. VR-P/K = variable rate phosphorus and potassium. VR-seeding $=$ variable rate seeding.

\section{Table 6}

Attitudinal determinants of adoption for temporal, nonspatial precision technologies and diagnostic precision technologies (survey-weighted ordered probit regression).

\begin{tabular}{lcccc}
\hline Variables & PSNT & Aerial scouting & $\begin{array}{l}\text { Soil nutrient } \\
\text { mapping }\end{array}$ & Yield mapping \\
\hline Income & -0.243 & 0.0277 & $-0.286 *$ & 0.0440 \\
& $(0.170)$ & $(0.172)$ & $(0.169)$ & $(0.184)$ \\
Environmental & -0.0125 & -0.0469 & -0.188 & -0.153 \\
& $(0.187)$ & $(0.175)$ & $(0.197)$ & $(0.194)$ \\
Social status & 0.426 & 0.276 & $0.584 * *$ & 0.231 \\
& $(0.289)$ & $(0.281)$ & $(0.280)$ & $(0.302)$ \\
Pseudo R-squared & 0.0914 & 0.139 & 0.0790 & 0.149 \\
\hline
\end{tabular}

Notes: Significance (t-test probability $>0$ ): $* * * 1 \% ; * * 5 \% ; * 10 \%$. Robust standard errors in parentheses. PSNT = pre-sidedress nitrate testing.

that working lands programs would affect the adoption of precision agriculture practices, we find evidence that participation in working lands programs boosts the probability of adopting PSNT and soil nutrient mapping (table 8; both of which can benefit from costshare subsidies in some districts).

As for risk management objectives, we find that the proportion of land with crop insurance increases the probability of adopting VR-P/K and yield mapping, but not any other precision technology (tables 7 and 8 ).

Farm Resource Drivers. Our results show that farmers who operate more cropland are more likely to adopt VR-N, VR-P/K, VR-Seeding, aerial scouting, and yield mapping (tables 7 and 8), which supports our hypothesis that that farms with more cropped acreage will be more inclined to adopt precision agriculture technologies, consistent with the existence of economies of scale for these technologies.
We find no evidence that farmers who own a larger proportion of the land they operate or farmers expecting to bequeath are more likely to adopt cover cropping (table 7), contrary to our hypotheses. Although we had no expectations that land tenure status would affect precision technology adoption, the results indicate that farmers who rent relatively more land are more likely to adopt aerial scouting (table 8). We also had no expectation that expecting to bequeath would drive the adoption of precision technologies, but we found that farmers who expect to bequeath their farm to an heir are more likely to adopt VR-N, aerial scouting, and yield mapping.

Information Access Drivers. We find that farmers with greater information access to university faculty are more likely to adopt VR-N, VR-Seeding, PSNT, aerial scouting and yield mapping, but not VR-P/K or soil mapping (tables 9 and 10). These findings suggest that greater access to public sources 
Table 7

Determinants of adoption of conservation practice and applicative precision technologies (surveyweighted ordered probit regression).

\begin{tabular}{|c|c|c|c|c|c|}
\hline \multirow[b]{2}{*}{ Variables } & \multirow[b]{2}{*}{$\begin{array}{l}\text { Unit of } \\
\text { measure }\end{array}$} & \multicolumn{4}{|c|}{ Dependent variables } \\
\hline & & $\begin{array}{l}\text { Cover } \\
\text { cropping }\end{array}$ & VR-N & VR-P/K & VR-Seeding \\
\hline Cropland & Acres & $\begin{array}{l}-3.62 \times 10^{-5} \\
\left(3.93 \times 10^{-5}\right)\end{array}$ & $\begin{array}{l}7.33 \times 10^{-5 *} \\
\left(3.95 \times 10^{-5}\right)\end{array}$ & $\begin{array}{l}0.000140 * * \\
\left(5.84 \times 10^{-5}\right)\end{array}$ & $\begin{array}{l}0.000155 * * * \\
\left(5.95 \times 10^{-5}\right)\end{array}$ \\
\hline Own land share & Proportion & $\begin{array}{l}-0.185 \\
(0.122)\end{array}$ & $\begin{array}{l}-0.0244 \\
(0.131)\end{array}$ & $\begin{array}{l}0.0438 \\
(0.131)\end{array}$ & $\begin{array}{l}-0.154 \\
(0.125)\end{array}$ \\
\hline Labor force & $\begin{array}{l}\text { Number of } \\
\text { persons }\end{array}$ & $\begin{array}{l}-0.00421 \\
(0.00683)\end{array}$ & $\begin{array}{l}0.00178 \\
(0.0127)\end{array}$ & $\begin{array}{l}-0.0175^{*} \\
(0.00948)\end{array}$ & $\begin{array}{l}-0.00112 \\
(0.0118)\end{array}$ \\
\hline Livestock farm & Binary & $\begin{array}{l}0.197 * \\
(0.111)\end{array}$ & $\begin{array}{l}-0.0816 \\
(0.114)\end{array}$ & $\begin{array}{l}-0.247 * * \\
(0.108)\end{array}$ & $\begin{array}{l}-0.132 \\
(0.101)\end{array}$ \\
\hline Age & Years & $\begin{array}{l}-0.00756^{*} \\
(0.00400)\end{array}$ & $\begin{array}{l}-0.00340 \\
(0.00412)\end{array}$ & $\begin{array}{l}-0.00665 \\
(0.00427)\end{array}$ & $\begin{array}{l}-0.0187 * * * \\
(0.00411)\end{array}$ \\
\hline Educational level & Integer & $\begin{array}{l}0.0494 \\
(0.0542)\end{array}$ & $\begin{array}{l}-0.00458 \\
(0.0550)\end{array}$ & $\begin{array}{l}-0.0570 \\
(0.0555)\end{array}$ & $\begin{array}{l}0.0786 \\
(0.0530)\end{array}$ \\
\hline $\begin{array}{l}\text { Crop insurance } \\
\text { enrollment }\end{array}$ & $\begin{array}{l}\text { Proportion } \\
\text { of crop } \\
\text { acres }\end{array}$ & $\begin{array}{l}-0.0992 \\
(0.113)\end{array}$ & $\begin{array}{l}-0.0611 \\
(0.122)\end{array}$ & $\begin{array}{l}0.263^{* *} \\
(0.112)\end{array}$ & $\begin{array}{l}0.179 \\
(0.113)\end{array}$ \\
\hline $\begin{array}{l}\text { Working lands } \\
\text { conservation } \\
\text { program } \\
\text { participator }\end{array}$ & Binary & $\begin{array}{l}0.822 * * * \\
(0.146)\end{array}$ & $\begin{array}{l}0.0172 \\
(0.108)\end{array}$ & $\begin{array}{l}0.0241 \\
(0.130)\end{array}$ & $\begin{array}{l}0.113 \\
(0.125)\end{array}$ \\
\hline Bequeath intent & Binary & $\begin{array}{l}0.151 \\
(0.0975)\end{array}$ & $\begin{array}{l}0.194 * \\
(0.101)\end{array}$ & $\begin{array}{l}-0.0155 \\
(0.101)\end{array}$ & $\begin{array}{l}0.136 \\
(0.0983)\end{array}$ \\
\hline Illinois & Binary & $\begin{array}{l}-0.442 * * * \\
(0.153)\end{array}$ & $\begin{array}{l}-0.135 \\
(0.182)\end{array}$ & $\begin{array}{l}-0.0628 \\
(0.160)\end{array}$ & $\begin{array}{l}-0.210 \\
(0.156)\end{array}$ \\
\hline Indiana & Binary & $\begin{array}{l}0.236 \\
(0.153)\end{array}$ & $\begin{array}{l}-0.362 * * \\
(0.177)\end{array}$ & $\begin{array}{l}0.0544 \\
(0.155)\end{array}$ & $\begin{array}{l}0.0557 \\
(0.160)\end{array}$ \\
\hline Ohio & Binary & $\begin{array}{l}0.435 * * * \\
(0.151)\end{array}$ & $\begin{array}{l}-0.273 \\
(0.174)\end{array}$ & $\begin{array}{l}-0.306 * * \\
(0.151)\end{array}$ & $\begin{array}{l}-0.116 \\
(0.154)\end{array}$ \\
\hline Pseudo R-squared & - & 0.107 & 0.0264 & 0.0515 & 0.110 \\
\hline
\end{tabular}

Notes: Significance (t-test probability $>0$ ): $* * * 1 \% ; * \star 5 \% ; * 10 \%$. Robust standard errors in parentheses. VR-N $=$ variable rate nitrogen. $\mathrm{VR}-\mathrm{P} / \mathrm{K}=$ variable rate phosphorus and potassium. VR-Seeding $=$ variable rate seeding .

of information on best management practices increases the likelihood of precision technology adoption. However, there is no evidence to suggest that access to public sources of information drives the decision to adopt cover cropping, suggesting that such information sources would have no effect on the adoption of conservation practices.

Although we had no expectations about the impacts of private information sources on precision technology practice adoption, we do find that farmers with access to chemical dealers are more likely to adoptVR-P/K and PSNT (tables 9 and 10). Access to private consultants increases the likelihood of adoption of all of the precision technologies. We also find that access to private consultants boosts the probability of adoption of cover cropping (tables 9 and 10).
Patterns across Drivers and Practices. Our findings highlight the importance of nonincome objectives in motivating the adoption of farming practices that abate soil nutrient losses. A pro-environmental attitude strongly augmented the likelihood of adopting cover cropping - an important conservation practice. This finding aligns with the literature on environmental awareness and attitudes as drivers of best management practice adoption (Prokopy et al. 2008; Baumgart-Getz et al. 2012). Likewise, a social status orientation favors adoption of at least some of the diagnostic precision agriculture practices.

Farm type is a significant factor in driving the decision to adopt best management practices. In particular, being a livestock farmer increases the likelihood of adopting cover cropping but decreases the probability of adopting precision technologies. Since cover crops can also serve as forage for livestock (Wardynski 2015), they offer a private feed benefit to supplement the mixed private-public soil conservation benefit, and farmers who raise grazing livestock may consequently be more likely to adopt. However, as information on the types of livestock raised was not elicited from respondents, we cannot distinguish between grazing livestock versus nongrazing livestock (e.g., hogs and feedlot cattle). If the private feed benefit is only realized for farmers who manage grazing livestock, then the effect for these farmers is likely even larger than the effect estimated in this study, as including managers of nongrazing livestock in the same category as managers of grazing livestock will bias our estimate toward zero. As hypothesized, livestock farmers also appear less inclined to invest in specialized equipment for fine-tuning crop management via precision technologies.

Policy incentives are designed to encourage the adoption of best management practices, and our research finds evidence of success. Participation in working lands programs was associated with the adoption of both cover cropping - a soil and nutrient retention practice - and PSNT - a crop nutrient diagnostic practice. As cover cropping and nutrient management practices are both eligible for cost-sharing under the Environmental Quality Incentive Program (EQIP), participation in EQIP reduces the initial cost of adoption for these practices (Newton 2019).

Other findings reinforce the existing literature. Age had a negative impact on the likelihood of adoption of five of eight practices, echoing much of the literature on the effects of age on adoption (Baumgart-Getz et al. 2012; Prokopy et al. 2008). Among the practices where younger farmers were more likely to adopt was cover cropping, although other research into conservation practices finds that older farmers are more likely to enroll in conservation programs (Yeboah et al. 2015). Education had a positive impact on the probability of adopting three precision technologies, concurring with literature on education's impacts on best management practice adoption (Prokopy et al. 2008; Pierpaoli et al. 2013). Scale of farming operation and access to capital, as indicated by cropland area operated, also contributed strongly to the likelihood of adopting five of the seven precision agriculture practices, but 
Table 8

Determinants of adoption for temporal, nonspatial precision technologies and diagnostic precision technologies (survey-weighted ordered probit regression).

\begin{tabular}{|c|c|c|c|c|c|}
\hline \multirow[b]{2}{*}{ Variables } & \multirow[b]{2}{*}{$\begin{array}{l}\text { Unit of } \\
\text { measure }\end{array}$} & \multicolumn{4}{|c|}{ Dependent variables } \\
\hline & & PSNT & $\begin{array}{l}\text { Aerial } \\
\text { scouting }\end{array}$ & $\begin{array}{l}\text { Soil nutrient } \\
\text { mapping }\end{array}$ & $\begin{array}{l}\text { Yield } \\
\text { mapping }\end{array}$ \\
\hline Cropland & Acres & $\begin{array}{l}1.11 \times 10^{-5} \\
\left(3.86 \times 10^{-5}\right)\end{array}$ & $\begin{array}{l}0.000101 * * \\
\left(4.75 \times 10^{-5}\right)\end{array}$ & $\begin{array}{l}6.46 \times 10^{-5} \\
\left(8.62 \times 10^{-5}\right)\end{array}$ & $\begin{array}{l}0.000500 * * * \\
\left(9.17 \times 10^{-5}\right)\end{array}$ \\
\hline Own land share & Proportion & $\begin{array}{l}-0.142 \\
(0.123)\end{array}$ & $\begin{array}{l}-0.323^{* *} \\
(0.125)\end{array}$ & $\begin{array}{l}-0.132 \\
(0.140)\end{array}$ & $\begin{array}{l}-0.189 \\
(0.130)\end{array}$ \\
\hline Labor force & $\begin{array}{l}\text { Number of } \\
\text { persons }\end{array}$ & $\begin{array}{l}0.0146 \\
(0.0132)\end{array}$ & $\begin{array}{l}0.0175 \\
(0.0124)\end{array}$ & $\begin{array}{l}0.0145 \\
(0.0214)\end{array}$ & $\begin{array}{l}-0.0120 \\
(0.0108)\end{array}$ \\
\hline Livestock farm & Binary & $\begin{array}{l}-0.126 \\
(0.105)\end{array}$ & $\begin{array}{l}-0.0466 \\
(0.108)\end{array}$ & $\begin{array}{l}-0.232 * * \\
(0.112)\end{array}$ & $\begin{array}{l}-0.472 * * * \\
(0.0979)\end{array}$ \\
\hline Age & Years & $\begin{array}{l}-0.000829 \\
(0.00411)\end{array}$ & $\begin{array}{l}-0.00815^{*} \\
(0.00438)\end{array}$ & $\begin{array}{l}-0.00813 * \\
(0.00493)\end{array}$ & $\begin{array}{l}-0.0125 * * * \\
(0.00426)\end{array}$ \\
\hline Educational level & Integer & $\begin{array}{l}-0.0624 \\
(0.0516)\end{array}$ & $\begin{array}{l}0.188 * * * \\
(0.0507)\end{array}$ & $\begin{array}{l}0.109 * \\
(0.0592)\end{array}$ & $\begin{array}{l}0.161 * * * \\
(0.0539)\end{array}$ \\
\hline $\begin{array}{l}\text { Crop insurance } \\
\text { enrollment }\end{array}$ & $\begin{array}{l}\text { Proportion } \\
\text { of crop acres }\end{array}$ & $\begin{array}{l}0.166 \\
(0.114)\end{array}$ & $\begin{array}{l}0.119 \\
(0.108)\end{array}$ & $\begin{array}{l}0.177 \\
(0.118)\end{array}$ & $\begin{array}{l}0.188^{*} \\
(0.110)\end{array}$ \\
\hline $\begin{array}{l}\text { Working lands } \\
\text { conservation } \\
\text { program participator }\end{array}$ & Binary & $\begin{array}{l}0.288 * * \\
(0.134)\end{array}$ & $\begin{array}{l}0.144 \\
(0.124)\end{array}$ & $\begin{array}{l}0.331 * * \\
(0.145)\end{array}$ & $\begin{array}{l}0.190 \\
(0.145)\end{array}$ \\
\hline $\begin{array}{l}\text { Set-aside } \\
\text { conservation } \\
\text { program participator }\end{array}$ & Binary & $\begin{array}{l}-0.0377 \\
(0.0972)\end{array}$ & $\begin{array}{l}-0.0581 \\
(0.0989)\end{array}$ & $\begin{array}{l}0.017 \\
(0.114)\end{array}$ & $\begin{array}{l}-0.0489 \\
(0.103)\end{array}$ \\
\hline Bequeath intent & Binary & $\begin{array}{l}0.125 \\
(0.0996)\end{array}$ & $\begin{array}{l}0.176 * \\
(0.0929)\end{array}$ & $\begin{array}{l}-0.0730 \\
(0.108)\end{array}$ & $\begin{array}{l}0.242 * * \\
(0.106)\end{array}$ \\
\hline Illinois & Binary & $\begin{array}{l}-0.196 \\
(0.161)\end{array}$ & $\begin{array}{l}0.202 \\
(0.149)\end{array}$ & $\begin{array}{l}0.0485 \\
(0.156)\end{array}$ & $\begin{array}{l}0.0519 \\
(0.155)\end{array}$ \\
\hline Indiana & Binary & $\begin{array}{l}-0.180 \\
(0.165)\end{array}$ & $\begin{array}{l}0.345 * * \\
(0.156)\end{array}$ & $\begin{array}{l}0.0394 \\
(0.149)\end{array}$ & $\begin{array}{l}-0.0433 \\
(0.151)\end{array}$ \\
\hline Ohio & Binary & $\begin{array}{l}-0.315^{*} \\
(0.165)\end{array}$ & $\begin{array}{l}0.153 \\
(0.148)\end{array}$ & $\begin{array}{l}-0.222 \\
(0.141)\end{array}$ & $\begin{array}{l}-0.211 \\
(0.149)\end{array}$ \\
\hline Pseudo R-squared & - & 0.0914 & 0.139 & 0.0790 & 0.149 \\
\hline
\end{tabular}

Notes: Significance (t-test probability $>0$ ): ***1\%; **5\%; *10\%. Robust standard errors in parentheses. PSNT $=$ pre-sidedress nitrate test.

not cover cropping. These findings corroborate with literature on the impacts of farm size on the adoption of precision technologies (Schimmelpfennig 2016). The share of land enrolled in crop insurance likewise favored adoption of precision agriculture practices, notably yield mapping. The failure of crop insurance to encourage adoption of conservation practices may be due to the fact that until 2017, the US Federal Crop Insurance Corporation did not have formal guidelines for conditions when cover crops would not interfere with an insurance claim. The link between expecting to bequeath the operation to an heir and the adoption of VR-N, aerial scouting, and yield mapping could be explained by either of two mechanisms. One would be that farmers who intend to bequeath the farm take a longer term, mul- tigenerational perspective. An alternative explanation would be that farmers who expect to bequeath to an heir often have that heir actively involved in management, so the bequeath variable may be picking up a generational effect. Information access across all sources had a positive (or insignificant) effect on the adoption of all practices, consistent with the literature (Prokopy et al. 2008). Notably, we find no significant effect on the probability of adoption of any practice from access to public extension services, though direct access to faculty is a positive determinant in the adoption of five of the seven precision agriculture technologies examined. We further find that access to private consultants, as well as access to print sources, raise the odds of conservation practice adoption. Private consultants proved to be the most consistently positive determinant of adopting nutrient abatement practices, with positive effects on the adoption of all eight practices examined.

Our results show that nutrient abatement technologies vary in the factors that drive farmers to adopt them. This finding echoes those reported in Prokopy et al. (2008) and Baumgart-Getz et al. (2012), suggesting that a single model on practice adoption cannot accurately apply to all practices and regions. Policymakers would do well to undertake a targeted approach in encouraging wider adoption of the practices that are the focus of this study. Since each technology appears to exhibit a unique set of traits of those adopting it, it may be worthwhile for informed policymakers to target farmers on a practice-by-practice basis, rather than through a one-size-fits-all approach.

While the ordered probit model does not provide coefficients that are readily converted into measurable marginal effects, we can infer increasing magnitudes of joint targeting efforts. For example, per table 8 , younger, better educated farmers are more inclined to adopt aerial scouting, soil nutrient mapping, and yield mapping. Farmers with more cropland who intend to bequeath their farms to the next generation are even more likely to adopt aerial scouting and yield mapping.

\section{Summary and Conclusions}

Policies that aim to encourage the voluntary adoption of cropping practices that abate crop nutrient loss need to be grounded in an understanding of the factors that motivate farmer adoption decisions. The large extant technology adoption literature provides a sound base for identifying major adoption determinants, including farmer traits, farm resources, technology traits, and access to information. In particular, these traits influence the adoption of conservation and precision agriculture practices that can abate crop nutrient loss, and can be used to assist policymakers in designing policy with incentives to attract those farmers who may be more amenable to adopting these practices.

Beyond the "usual suspect" drivers of farm technology adoption, we find that key roles are played by farmer objectives beyond income, technological compatibility with existing farm systems (i.e. farm type), and the presence of policy incentives. Environmental objectives, captured here by a latent environmental attitudinal factor, boost the likelihood 


\section{Table 9}

Information access determinants of adoption of conservation practice and applicative precision technologies (survey-weighted ordered probit regression).

\begin{tabular}{llllll}
\hline & & Dependent variables & & \\
\cline { 3 - 5 } Variables & Unit of measure & Cover cropping & VR-N & VR-P/K & \multicolumn{1}{l}{ VR-Seeding } \\
\hline Info: extension & 5-point Likert & $0.0997(0.0733)$ & $-0.0266(0.0720)$ & $0.0290(0.0842)$ & $0.0595(0.0801)$ \\
Info: faculty & 5-point Likert & $-0.0328(0.0731)$ & $0.214 * * *(0.0713)$ & $0.0416(0.0755)$ & $0.161 * *(0.0779)$ \\
Info: chemical dealer & 5-point Likert & $0.0566(0.0824)$ & $0.0545(0.0761)$ & $0.176 * *(0.0809)$ & $0.0514(0.0786)$ \\
Info: seed dealer & 5-point Likert & $-0.0625(0.0819)$ & $-0.0426(0.0776)$ & $0.0186(0.0796)$ & $-0.0412(0.0770)$ \\
Info: independent consultant & 5-point Likert & $0.166 * *(0.0504)$ & $0.0868 *(0.0511)$ & $0.143 * *(0.0557)$ & $0.164 * *(0.0489)$ \\
Info: other farmers & 5-point Likert & $0.0698(0.0479)$ & $0.0529(0.0537)$ & $-0.116 * *(0.0589)$ & $0.0267(0.0526)$ \\
Info: growers associations & 5-point Likert & $0.0372(0.0644)$ & $-0.0157(0.0626)$ & $0.00246(0.0658)$ & $0.0888(0.0688)$ \\
Info: web & 5-point Likert & $0.0167(0.0382)$ & $0.0176(0.0382)$ & $0.0815 * *(0.0393)$ & $0.0581(0.0357)$ \\
Info: print & 5-point Likert & $0.0828 *(0.0499)$ & $-0.0211(0.0549)$ & $0.0783(0.0551)$ & $0.0834(0.0532)$ \\
Pseudo R-squared & - & 0.107 & 0.0264 & 0.0515 & 0.110 \\
\hline
\end{tabular}

Notes: Significance (t-test probability $>0): * * * 1 \% ; * * 5 \% ; * 10 \%$. Robust standard errors in parentheses. VR-N $=$ variable rate nitrogen. VR-P/K $=$ variable rate phosphorus and potassium. VR-Seeding $=$ variable rate seeding.

\section{Table 10}

Information access determinants of adoption for temporal, nonspatial precision technologies and diagnostic precision technologies (survey-weighted ordered probit regression).

\begin{tabular}{|c|c|c|c|c|c|}
\hline \multirow[b]{2}{*}{ Variables } & \multirow[b]{2}{*}{ Unit of measure } & \multicolumn{4}{|l|}{ Dependent variables } \\
\hline & & PSNT & Aerial scouting & Soil nutrient mapping & Yield mapping \\
\hline Info: extension & 5-point Likert & $-0.0592(0.0836)$ & $-0.0342(0.0811)$ & $0.0769(0.0823)$ & $-0.0113(0.0825)$ \\
\hline Info: chemical dealer & 5-point Likert & $0.171 * *(0.0771)$ & $0.0508(0.0815)$ & $-0.0318(0.0897)$ & $0.0544(0.0897)$ \\
\hline Info: seed dealer & 5-point Likert & $-0.0289(0.0736)$ & $0.0549(0.0798)$ & $0.136(0.0921)$ & $-0.00947(0.0888)$ \\
\hline Info: growers associations & 5-point Likert & $0.0505(0.0703)$ & $0.0236(0.0727)$ & $0.0453(0.0700)$ & $0.164 * *(0.0691)$ \\
\hline Info: web & 5-point Likert & $0.0971 * *(0.0394)$ & $0.148 * * *(0.0381)$ & $0.0205(0.0433)$ & $0.0663 *(0.0400)$ \\
\hline Info: print & 5-point Likert & $-0.0256(0.0534)$ & $0.107 * *(0.0511)$ & $0.137 * *(0.0581)$ & $0.000182(0.0522)$ \\
\hline Pseudo R-squared & - & 0.0914 & 0.139 & 0.0790 & 0.149 \\
\hline
\end{tabular}

Notes: Significance (t-test probability $>0$ ): ***1\%; $* * 5 \%$; $* 10 \%$. Robust standard errors in parentheses. PSNT = pre-sidedress nitrate test.

of adopting a conservation practice like cover cropping. Likewise, social status seeking is associated with adoption of nutrient mapping and (in the unweighted model) aerial scouting. These findings suggest that adoption of these practices can potentially be enhanced if government agencies target farmers with these objectives.

Program targeting can also benefit by understanding how farm types align with the appeal of specific farming practices. Livestock farmers are drawn to practices that can reduce their feed costs (like cover crop production), but they have limited time and money to invest in crop-specific technologies without a notable livestock benefit (like precision agriculture practices).
Where incentive policies align with farmer objectives, they can be effective at inducing adoption of environmentally beneficial practices. This connection is illustrated by the fact that adoption of cover crops and the PSNT are both eligible for cost sharing under EQIP, and that participation in working lands programs (like EQIP) was a significant driver of the adoption of both practices.

An important caveat regarding adoption of multiple practices is that farmers' adoption decisions are not independent of one another (Wachenheim and Lesch 2014). Further, some practices are most effective when adopted jointly. With these factors in mind, policymakers can be most effective in targeting programs to encourage adoption of conservation practices if they recognize connections between practices and suitability to specific kinds of farms.

The design of effective, voluntary conservation policy hinges on tailoring the policy to the farmer, the farm, the biophysical setting, the market setting, and the technologies at hand. This research sheds fresh light on the roles of farmer objectives and the farm-technology match, especially for effective policy targeting. It further illustrates that well-designed, targeted conservation incentives can have sustained influence on the adoption of nutrient abatement practices. 


\section{Acknowledgements}

The authors acknowledge financial support for this research from the National Science Foundation Long-term Ecological Research Program (DEB 1832042) at the Kellogg Biological Station, Michigan State University AgBioResearch, and the USDA National Institute of Food and Agriculture. They also thank Sandra Marquart-Pyatt (professor, Department of Sociology, Michigan State University, East Lansing, Michigan), Riva Denny (postdoctoral research fellow, School for Environment and Sustainability, University of Michigan, Ann Arbor, Michigan), and Matthew Houser (research fellow, Environmental Resilience Institute, Indiana University, Bloomington, Indiana) for input on survey design, two anonymous reviewers for helpful comments, the hard-working team of undergraduate data coders, and most of all, the respondents to the 2017 Crop Management and Stewardship Practices survey.

\section{References}

Abadi Ghadim, A.K., and D.J. Pannell. 1999. A conceptual framework of adoption of an agricultural innovation. Agricultural Economics 21:145-154.

Baumgart-Getz, A., L.S. Prokopy, and K. Floress. 2012. Why farmers adopt best management practice in the United States: A meta-analysis of the adoption literature. Journal of Environmental Management 96:17-25.

Besley, T., and A. Case. 1993. Modeling technology adoption in developing countries. American Economic Review 83:396-402.

Chouinard, H.H., T. Paterson, P.R. Wandschneider, and A.M. Ohler. 2008. Will farmers trade profits for stewardship? Heterogeneous motivations for farm practice selection. Land Economics 84(1):66-82.

Claassen, R., J. Horowitz, E. Duquette, and K. Ueda. 2014. Additionality in U.S. Agricultural Conservation and Regulatory Offset Programs. Economic Research Report 170. Washington, DC: USDA Economic Research Service.

Conley, T.G., and C.R. Udry. 2010. Learning about a new technology: Pineapple in Ghana. American Economic Review 100:35-69.

Daberkow, S.G., and W.D. McBride. 2003. Farm and operator characteristics affecting the awareness and adoption of precision agriculture technologies in the US. Precision Agriculture 4:163-177.

Feder, G., R.E. Just, and D. Zilberman. 1985. Adoption of agricultural innovations in developing countries: A survey. Economic Development and Cultural Change 33:255-298.

Feder, G., and D.L. Umali. 1993. The adoption of agricultural innovations: A Review. Technological Forecasting and Social Change 43:215-239.

Finger, R., S.M. Swinton, N. El-Benni, and A.M. Walter. 2019. Precision farming at the nexus of agricultural production and the environment. Annual Review of Resource Economics 11:313-335.

Fleming, P. 2017. Agricultural cost sharing and water quality in the Chesapeake Bay: Estimating indirect effects of environmental payments. American Journal of Agricultural Economics 99:1208-1227.

Gebremedhin, B., and S.M. Swinton. 2003. Investment in soil conservation in Ethiopia: The role of land tenure security and public programs. Agricultural Economics 29:69-84.

Greiner, R., and D. Gregg. 2011. Farmers' intrinsic motivations, barriers to the adoption of conservation practices and effectiveness of policy instruments: Emperical evidence from northern Australia. Land Use Policy 28:257-265.

Hunecke, C., A. Engler, R. Jara-Rojas, and P.M. Poortvliet. 2017. Understanding the role of social capital in adoption decisions: An application to irrigation technology. Agricultural Systems 153:221-231.

King, K.W., M.R. Williams, M.L. Macrae, N.R. Fausey, J. Frankenberger, D.R. Smith, P.J. Kleinman, and L.C. Brown. 2015. Phosphorus transport in agricultural subsurface drainage: A review. Journal of Environmental Quality 44:467-485.

Knowler, D., and B. Bradshaw. 2007. Farmers' adoption of conservation agriculture: A review and synthesis of recent research. Food Policy 32:25-48.

Krause, M.A., R.R. Deuson, T.G. Baker, P.V. Preckel, J. Lowenberg-DeBoer, K.C. Reddy, and K. Maliki. 1990. Risk sharing versus low-cost credit systems for international development. American Journal of Agricultural Economics 72:911-922.

Lichtenberg, E., and R. Smith-Ramirez. 2011. Slippage in conservation cost sharing. American Journal of Agricultural Economics 93:1-17.

Mascia, M.B., and M. Mills. 2018. When conservation goes viral: The diffusion of innovative biodiversity conservation policies and practices. Conservation Letters 11(3):e12442.

Maybery, D., L. Crase, and C. Gullifer. 2005. Categorising farming values as economic, conservation and lifestyle. Journal of Economic Psychology 26:59-72.

Mezzatesta, M., D. Newburn, and R. Woodward. 2013. Additionality and the adoption of farm conservation practices. Land Economics 89:722-742.

Micheels, E.T., and J.F. Nolan. 2016. Examining the effects of absorptive capacity and social capital on the adoption of agricultural innovations: A Canadian Prairie case study. Agricultural Systems 145:127-138.

Newton, J. 2019. EQIP and CSP Conservation Programs in the 2018 Farm Bill. Washington, DC: American Farm Bureau Federation. https://www.fb.org/market-intel/ eqip-and-csp-conservation-programs-in-the-2018farm-bill.

Pannell, D.J., G.R. Marshall, N. Barr, A. Curtis, F. Vanclay, and R. Wilkinson. 2006. Understanding and promoting adoption of conservation practices by rural landholders. Australian Journal of Experimental Agriculture 46:1407-1424.
Pierpaoli, E., G. Carli, E. Pignatti, and M. Canavari. 2013. Drivers of precision agriculture technologies adoption: A literature review. Procedia Technology 8:61-69.

Pimentel, D., C. Harvey, P. Resosudarmo, K. Sinclair, D. Kurz, M. McNair, S. Crist, L. Shpritz, L. Fitton, R. Saffouri, and R. Blair. 1995. Environmental and economic costs of soil erosion and conservation benefits. Science 267:1117-1123.

Prokopy, L.S., K. Floress, J.G. Arbuckle, S.P. Church, F.R. Eanes, Y. Gao, B.M. Gramig, P. Ranjan, and A.S. Singh. 2019. Adoption of agricultural conservation practices in the United States: Evidence from 35 years of quantitative literature. Journal of Soil and Water Conservation 74(5):520-534, doi:10.2489/jswc.74.5.520.

Prokopy, L.S., K. Floress, D. Klotthor-Weinkauf, and A. Baumgart-Getz. 2008. Determinants of agricultural best management practice adoption: Evidence from the literature. Journal of Soil and Water Conservation 63:300-311, doi:10.2489/jswc.63.5.300.

Ranjan, P., S.P. Church, K. Floress, and L.S. Prokopy. 2019. Synthesizing conservation motivations and barriers: What have we learned from qualitative studies of farmers' behaviors in the United States? Society \& Natural Resources 32(11):1171-1199.

Roesch-McNally, G., J.G. Arbuckle, and J.C. Tyndall. 2018. Soil as social-ecological feedback: Examining the "ethic" of soil stewardship among Corn Belt farmers. Rural Sociology 83(1):145-173.

Schimmelpfennig, D.E. 2016. Farm Profits and Adoption of Precision Agriculture. Economic Research Report 217. Washington, DC: USDA Economic Research Service. http://www.ers.usda.gov/publications/ pub-details/?pubid $=80325$.

Selman, M., and S. Greenhalgh. 2009. Eutrophication:Policies, actions, and strategies to address nutrient pollution. Washington, DC: World Resources Institute. https:// www.wri.org/publication/eutrophication-policiesaction-and-strategies-address-nutrient-pollution.

Solon, G., S.J. Haider, and J.M. Wooldridge. 2015. What are we weighting for? Journal of Human Resources 50:301-316

Traxler, G., and D. Byerlee. 1993. A joint-product analysis of the adoption of modern cereal varieties in developing countries. American Journal of Agricultural Economics 75:981-989.

Wachenheim, C.J., and W.C. Lesch. 2014. Understanding landowner decision drivers regarding conversation through research. Western Economics Forum 13(2):21-28.

Wardynski, F. 2015. Cover crops as a livestock feed. East Lansing, MI: Michigan State University Extension. https://www.canr.msu.edu/news/ cover_crops_as_a_livestock_feed.

Yeboah, F.K., F. Lupi, and M.D. Kaplowitz. 2015. Agricultural landowners' willingness to participate in a filter strip program for watershed protection. Land Use Policy 49:75-85. 